\title{
PENENTUAN KOMPOSISI BAHAN MAKANAN BAGI PENDERITA GAGAL GINJAL AKUT DENGAN ALGORITMA GENETIKA
}

\author{
Agnes Rossi Trisna Lestari ${ }^{1}$, Umi Rofiqoh², Siti Robbana ${ }^{3}$, Winda Estu Nurjanah ${ }^{4}$, Ulfa Lina Wulandari ${ }^{5}$, \\ Imam Cholissodin 6 \\ 1,2,3,4,5,6Fakultas Ilmu Komputer Universitas Brawijaya \\ Email: ${ }^{1}$ agnesrossi.46@gmail.com, ${ }^{2}$ umi.roffi@gmail.com, ${ }^{3}$ robbana18@gmail.com, ${ }^{4}$ windaestu@ gmail.com, \\ ${ }^{5}$ ulfalinaw@gmail.com ${ }^{6}$ imamcs@ub.ac.id
}

(Naskah masuk: 4 Januari 2017, diterima untuk diterbitkan: 23 Januari 2017)

\begin{abstract}
Abstrak
Penyakit ginjal merupakan penyakit yang ganas, dimana jika penanganan yang dilakukan secara tidak tepat, maka akan mempengaruhi kualitas hidup penderitanya. Selain mengandalkan perawatan medis, individu yang menderita penyakit ini harus sadar diri dengan kondisi kesehatannya. Untuk mengatur diet makanannya, penderita memerlukan suatu sistem yang mampu menentukan komposisi bahan makanan bagi penderita penyakit ginjal secara cepat dan tepat. Oleh karena itu penulis memberikan solusi berupa sistem penentuan bahan makanan apa saja yang tepat gizi bagi penderita penyakit ginjal akut menggunakan algoritma genetika, dimana pengodean yang digunakan adalah real code. Nilai Gizi dari makanan diambil dari PUGS (Pedoman Umum Gizi Seimbang) dan ensiklopedi. Algoritma yang digunakan dalam penentuan komposisi bahan makanan bagi penderita gagal ginjal akut ini ialah algoritma genetika, langkahnya meliputi : inisialisasi kromosom dimana setiap kromosom terdapat 5 gen berupa indeks dari bahan makanan, kemudian dilakukan inisialisasi probabilitas crossover dan mutasi untuk proses reproduksi, dilanjutkan dengan evaluasi menggunakan perhitungan fitness yang disesuaikan dengan rumus, dan tahap akhir ialah melakukan seleksi dengan menggunakan elitism selection untuk menghasilkan kandidat bahan makanan baru untuk diproses pada iterasi berikutnya.
\end{abstract}

Kata kunci: komposisi bahan makanan, gagal ginjal akut, algoritma genetika

\begin{abstract}
Kidney disease is a malignant disease, where if the treatment is done incorrectly, the sufferer's quality of life can be affected by incorrect treatment. In addition to relying on medical care, individuals who suffer from this disease should be aware of themselves with the condition of his health. To arrange food diet, the patient requires a system that can determine the composition of food for kidney disease quickly and accurately. Therefore, the authors provide a solution with determination system for any food ingredient proper nutrition for patients with chronic kidney disease using genetic algorithms, where the coding used is real code. Nutritional value of food taken from PUGS (General Guidelines Balanced Nutrition) and encyclopedia. The algorithm used in determining the composition of foodstuffs for patients with acute renal failure this is a genetic algorithm, the steps include: initialization chromosome where each chromosome there are five genes in the form of index of groceries, then do the initialization probability of crossover and mutation to the reproductive process, followed by an evaluation using fitness calculations to the formula, and the final stage is to make the selection by using elitism candidate selection to produce new food material to be processed in the next iteration.
\end{abstract}

Keywords: food composition, acute renal failure, genetic algorithm

\section{PENDAHULUAN}

Indonesia merupakan negara yang memiliki penduduk yang padat, mencapai 225 juta populasi (menurut www.bps.go.id/). Dengan adanya laju penduduk yang semakin pesat, berbagai permasalahan timbul di negara ini. Salah satu permasalahannya adalah di bidang kesehatan, dimana Negara ini merupakan Negara yang menduduki urutan tertinggi ketiga terkait dengan penyakit katastropik yaitu penyakit ginjal. Dari data Kementrian Kesehatan Republik indonesia, tercatat sebanyak 3.094.915 penduduk Indonesia menderita penyakit ginjal dan (menurut www.depkes.go.id/). Untuk menjaga kondisi kesehatan tersebut diperlukan diet makanan yang sesuai dengan level penyakit ginjal, karena setiap level penyakit ginjal ini mempunyai perbedaan dalam pemilihan komposisi makanannya untuk permasalahan ini penulis memfokuskan ke penyakit ginjal akut. Dalam hal ini diperlukan perhitungan kebutuhan gizi secara khusus dan penerapannya dalam bentuk modifikasi diet atau diet khusus untuk penderita penyakit ginjal (Almatsier, 2008).

Oleh karena itu dibutuhkan suatu sistem untuk menentukan komposisi bahan makanan bagi penderita penyakit ginjal secara cepat dan tepat. 
Penulis memberikan solusi berupa sistem penentuan bahan makanan apa saja yang tepat gizi bagi penderita penyakit ginjal akut menggunakan algoritma genetika, dimana pengodean yang digunakan adalah real code. Untuk mendapatkan nilai fitness penyakit ginjal akut diperlukan pertimbangan khusus terkait kebutuhan kalori, protein, lemak, kalium, fosfor, kalsium dan kebutuhan karbohidrat penderitanya (Rismawan, 2007). Dengan adanya buku Pedoman Umum Gizi Seimbang (PUGS) penulis mampu mengetahui nilai gizi yang tepat.

Pada penelitian sebelumnya algoritma genetika diterapkan untuk permasalahan penjadwalan menu makanan bagi pasien Rumah sakit (Isokawa, 2014), dimana perhitungan fitnessnya belum dipaparkan secara jelas, namun penelitian tersebut mampu menghasilkan penjadwalan menu makanan yang tepat dan cepat. Untuk perbedaan penelitian yang dilakukan penulis dan penelitian sebelumnya terkait penentuan komposisi bahan makanan bagi penderita penyakit ginjal dengan algoritma genetika ini adalah dari segi perhitungan fitnessnya dan terfokus pada satu objek saja, dimana dengan adanya perhitungan fitness dan terfokus pada satu objek penyakit saja, yaitu penyakit ginjal akut diharapkan mampu keluar dari lokal optimal sehingga mampu mendapatkan global optimal yang lebih baik dari penelitian sebelumnya.

Dengan adanya penelitian ini, diharapkan penderita penyakit ginjal mampu menjaga kualitas hidupnya dengan berpedoman dengan sistem penentuan komposisi bahan makanan ini, sehingga dana yang seharusnya diberikan untuk perawatan medis dapat dipergunakan untuk kebutuhan penting lainnya. (Hartati, 2011).

\section{DASAR TEORI}

\subsection{Nutrisi Seimbang bagi Penderita Penyakit Gagal Ginjal Akut}

Nutrisi adalah substansi organik yang dibutuhkan makhluk hidup untuk fungsi normal dari sistem tubuh, pertumbuhan dan memelihara kesehatan. Nutrisi didapatkan dari makanan dan cairan yang dikonsumsi yang kemudian diasimilasi oleh tubuh. Makanan sehari-hari yang dipilih dan dikonsumsi dengan baik akan memberikan semua zat gizi yang dibutuhkan untuk fungsi normal tubuh. Sebaliknya, jika makan tidak dipilih dengan baik, tubuh akan mengalami kekurangan zat-zat gizi esensial tertentu (Almatsier, 2003).

Ada beberapa cara menentukan Angka Metabolisme Basal (AMB), salah satunya adalah rumus Harris Benedict (1919). Untuk menentukan Angka Metabolisme Basal (AMB) menurut Harris Benedict (1919).

Laki-laki $=66+(13,7 \mathrm{xBB})+(5 \mathrm{xTB})-(6,8 \mathrm{xU})$

Perempuan $=655+(9,6 \times B B)+(1,8 \times T B)-(4,7 \times U)(2)$
Keterangan :

$\mathrm{BB}=$ berat badan dalam $\mathrm{kg}$

$\mathrm{TB}=$ tinggi badan dalam $\mathrm{cm}$

$\mathrm{U}=$ umur dalam tahun

Sedangkan untuk mencari kebutuhan energi dapat menggunakan rumus (3).

Kebutuhan energi $=\mathrm{AMB} \mathrm{x}$ faktor aktivitas $\mathrm{x}$ faktor trauma/stress (3)

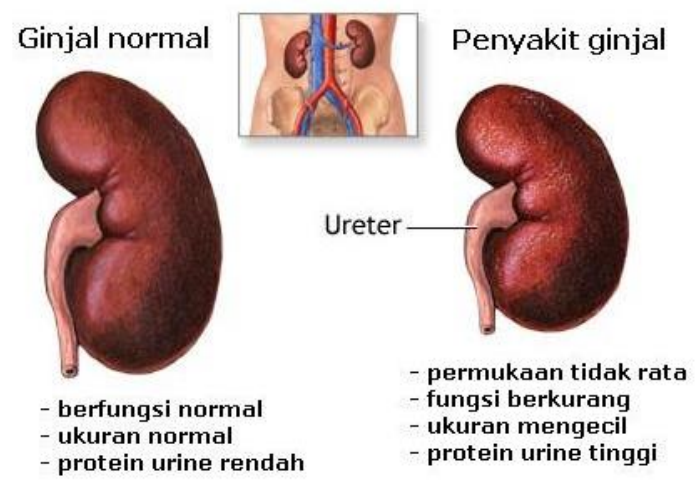

Gambar 1. Penyakit Ginjal

Pada Gambar 1, ginjal memiliki fungsi utama yaitu, memelihara keseimbangan homeostatik cairan, elektrolit dan bahan-bahan organik dalam tubuh. Diet khusus diperlukan jika fungsi ginjal terganggu. Diet pada penyakit ginjal ditekankan pada pengontrolan asupan energi, protein, cairan, elektrolit natrium, kalium, kalsium dan fosfor.

\subsection{Algoritma Genetika}

Algoritma genetika merupakan algoritma yang terinspirasi dari teori evolusi makhluk hidup yang menggunakan prinsip seleksi alam dan menggunakan beberapa operator genetika seperti halnya, crossover, mutasi dan seleksi. Pseudocode dari algoritma genetika pada Tabel 1 .

Tabel 1. Pseudocode Algoritma Genetika

\begin{tabular}{|c|l|}
\hline 1 & Inisialisasi generasi $\mathrm{t} \leftarrow 0$ \\
2 & Inisialisasi populasi $\mathrm{P}(0)$ secara acak \\
3 & Evaluasi semua individu pada $\mathrm{P}(0)$ \\
4 & Ulangi \\
5 & Pilih beberapa individu dari $\mathrm{P}(\mathrm{t})$ \\
6 & yang berpotensi untuk dilakukan \\
7 & crossover \\
8 & Lakukan crossover untuk menghasilkan \\
9 & Ganti $\mathrm{P}(\mathrm{t})$ dengan populasi baru \\
10 & Inisialisasi generasi $\mathrm{t} \leftarrow \mathrm{t}+1$ \\
\hline
\end{tabular}

Algoritma genetika mengkodekan beberapa variabel keputusan atau beberapa parameter input dari permasalahan kedalam beberapa string solusi yang memiliki panjang yang telah ditentukan. 


\subsubsection{Representasi dan Inisialisasi kromosom secara acak}

Ilustrasi sederhana representasi dan inisialisasi kromosom yang dilakukan secara random, yang ditunjukkan pada Tabel 2. Dimana dalam 1 kromosom terdiri dari 5 gen, yang setiap gen nya berisi indeks dari tiap bahan makanan.

Tabel 2. Representasi dan Inisialisasi kromosom

\begin{tabular}{|c|c|c|c|c|c|}
\hline Kromosomke - & \multicolumn{5}{|c|}{ Gen } \\
\hline 1 & 01 & 31 & 29 & 21 & 11 \\
\hline 2 & 02 & 21 & 16 & 30 & 11 \\
\hline 3 & 03 & 25 & 18 & 30 & 12 \\
\hline 4 & 04 & 19 & 22 & 11 & 29 \\
\hline 5 & 05 & 20 & 26 & 11 & 31 \\
\hline 6 & 06 & 12 & 30 & 24 & 35 \\
\hline 7 & 07 & 17 & 30 & 24 & 37 \\
\hline
\end{tabular}

Misalkan pada Tabel 2 berisikan indeks berupa bahan makanan, yaitu :

01 Beras Var Pelita I/1, 31 Anggur, 29 Tomat Merah, 21 Katuk, dan 11 Ubi manis.

02 Beras Var Pelita II/1, 21 Katuk, 16 Kacang Koro, 30 Wortel, dan 11 Ubi manis.

03 Beras Var Rojolele, 25 Kangkung, 18 Bayam, 30 Wortel, dan 12 Jengkol.

04 Beras Merah, 19 Buncis, 22 Kol Sawi, 11 Ubi manis, dan 29 Tomat Merah.

05 Gandum, 20 Bunga Pepaya, 26 Selada Air, 11 Ubi manis, dan 31Anggur.

06 Jagung, 12 Jengkol, 30 Wortel, 24 Ubi jalar, dan 35 Telur ayam lokal.

07 Ganyong, 17 Lamtoro, 30 Wortel, 24 Ubi jalar, dan 37 Belut.

\subsubsection{Inisialisasi probability crossover dan mutasi}

Inisialisasi probability crossover $(p c=0,8)$ dan probability mutasi $(p m=0,3)$ ditunjukkan pada Tabel 3. Proses ini akan menghasilkan offspring dengan mengalikan pc atau pm dengan jumlah popsize / jumlah kromosom (seluruh popsize/kromosom=37 kromosom).

Tabel 3. Inisialisasi probability crossover dan probability mutasi

\begin{tabular}{|c|c|c|}
\hline $\begin{array}{c}\text { Jenis } \\
\text { probability }\end{array}$ & Nilai & Offspring \\
\hline Crossover & 0.8 & 30 \\
\hline Mutasi & 0.3 & 11 \\
\hline
\end{tabular}

Dengan nilai offspring masing-masing crossover dan mutasinya adalah 30 dan 11 .

\subsubsection{Proses Reproduksi (Crossover)}

Proses reproduksi dengan crossover. Proses ini mengambil 2 pasang kromosom secara random sehingga menghasilkan beberapa offspring yang ditunjukkan pada Tabel 4.

Tabel 4. Proses Reproduksi dengan Crossover

\begin{tabular}{|c|c|c|c|c|c|c|}
\hline \multicolumn{7}{|c|}{ Crossover menghasilkan 0,8 × 37 = 30 offspring } \\
C1 = P1 + a (P2 - P1), a = 0.1104 \\
\hline \multicolumn{7}{|c|}{ Kromosom ke- } \\
\hline 2 & 02 & 21 & 16 & 30 & 11 & 0.003087533 \\
\hline 3 & 03 & 25 & 18 & 30 & 12 & 0.002926097 \\
\hline \multicolumn{7}{|c|}{ Offspring } \\
\hline C1 & 3 & 22 & 17 & 30 & 12 & 0.003059419 \\
\hline C2 & 3 & 25 & 18 & 30 & 12 & 0.002926097 \\
\hline
\end{tabular}

Pada Tabel 4 ditunjukan bahwa nilai fitness untuk kromosom ke 2 sebesar 0.003087533 dan kromosom ke 3 sebesar 0.002926097. Dengan nilai fitness untuk offspring $C 1$ dan $C 2$ yang dihasilkan melalui reproduksi crossover adalah 0.003059419 dan 0.002926097.

\subsubsection{Proses Reproduksi (Mutasi)}

Proses reproduksi dengan mutasi. Proses ini mengambil 2 pasang kromosom secara random sehingga menghasilkan beberapa offspring yang yang ditunjukkan pada Tabel 5.

Tabel 5. Proses Reproduksi dengan Mutasi

\begin{tabular}{|c|c|c|c|c|c|c|}
\hline \multicolumn{7}{|c|}{ Mutasi menghasilkan $0,3 \times 37=11$ offspring } \\
\hline \multicolumn{6}{|c|}{ Kromosom ke- } & Fitness \\
\hline 5 & 05 & 20 & 26 & 11 & 31 & 0.002876433 \\
\hline 6 & 06 & 12 & 30 & 24 & 35 & 0.002851391 \\
\hline \multicolumn{6}{|c|}{ Offspring } & Fitness \\
\hline C1 & 5 & 22 & 28 & 13 & 33 & 0.002905761 \\
\hline $\mathrm{C} 2$ & 6 & 14 & 32 & 26 & 37 & 0.003036503 \\
\hline
\end{tabular}

Pada Tabel 5 ditunjukan bahwa nilai fitness untuk kromosom ke 5 sebesar 0.002876433 dan kromosom ke 6 sebesar 0.002851391. Dengan nilai fitness untuk offspring $C 1$ dan $C 2$ yang dihasilkan melalui reproduksi mutasinya adalah 0.002905761 dan 0.003036503 .

\subsubsection{Evaluasi}

Melakukan evaluasi dengan perhitungan nilai fitness sesuai dengan rumus :

$$
f=\frac{1}{\left(\left(a b s\left(p-\sum a\right)+a b s\left(q-\sum b\right)+a b s\left(r-\sum c\right)\right)+b i l k e c i l\right)}
$$

Keterangan :

$p=$ energi yang dibutuhkan

$q=$ protein yang dibutuhkan dalam 1 hari untuk diet 
$r=$ lemak yang dibutuhkan dalam 1 hari untuk diet

$a=$ jumlah kalori pada bahan makanan

$b=$ jumlah protein pada bahan makanan

$c=$ jumlah lemak pada bahan makanan

bilkecil $=$ nilai untuk menjauhi pengurangan dengan 0

\subsubsection{Seleksi dengan Elitism}

Hasil seleksi dengan menggunakan elitism selection yang ditunjukkan pada Tabel 6. Dilakukan perbandingan nilai fitness antara kromosom parent dengan kromosom child, nilai fitness terbesar akan menjadi kandidat untuk dilakukan iterasi selanjutnya.

Tabel 6. Proses Elitism Selection

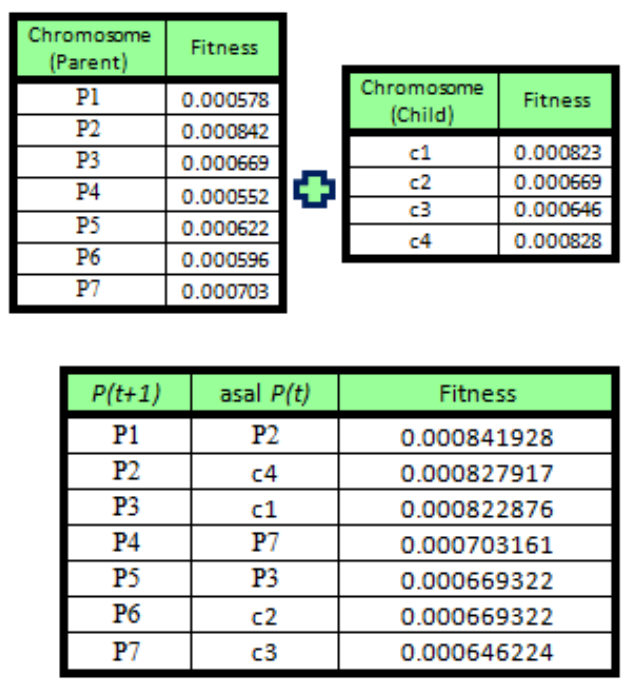

Pada Tabel 6 ditunjukan bahwa seleksi elitism bekerja dengan mengumpulkan semua individu dalam chromosome (parent) dan offspring dalam satu penampungan. Individu dengan nilai fitness terbaik sebanyak popSize dalam penampungan ini akan lolos untuk masuk dalam generasi selanjutnya.

\section{PERANCANGAN DAN IMPLEMENTASI}

Langkah awal proses ini adalah merepresentasikan dan menginisialisasi kromosom, probability crossover dan mutasi. Setelah langkah awal terinisialisasi, dilakukan pengujian dengan memasukkan data berupa usia, jeinis keliamin, usia, aktivitias fisik, berat badan, tinggi badan, dan jumlah kombinasi penentuan bahan makanan yang akan ditampilkan ke user dalam satuan hari. Kemudian dilakukan reproduksi dengan crossover dan mutasi, kemudian dilakukan evaluasi dengan perhitungan fitness, dilakukan seleksi dengan menggunakan metode elitism sehingga sistem mampu menampilkan kombinasi bahan makanan yang tepat bagi penderita pernyakit gagal ginjal akut.

Rancangan sistem penentuan komposisi bahan makanan bagi penderita penyakit gagal ginjal akut dengan algoritma genetika yang ditunjukkan oleh Gambar 2.

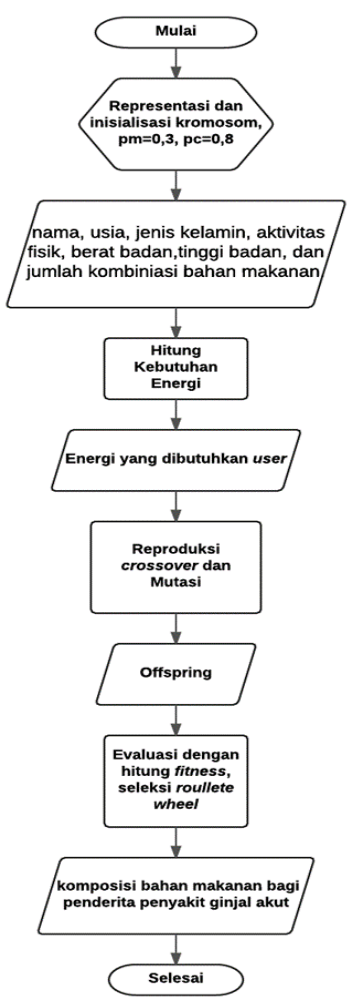

Gambar 2. Diagram Alir Sistem

Tabel 7 Kode Program Sistem ini digunakan sebagai proses perhitungan fitness dari komposisi bahan makanan bagi penderita gagal ginjal akut, dimana jika fitness yang didapatkan semakin tinggi maka komposisi bahan makanan tersebut akan menjadi pilihan alternative yang optimal bagi penderita gagal ginjal akut.

Tabel 7. Kode Program Sistem

\begin{tabular}{|c|c|c|}
\hline No & \multicolumn{2}{|l|}{ Kode Program } \\
\hline 1 & public function & \\
\hline 2 & evaluation (\$chromosome, \$energy, $\$$ & otein, \$fa \\
\hline 3 & t) \{ & \\
\hline 4 & $\$$ bilkecil = ra & $(1,5)$; \\
\hline 5 & & \\
\hline 6 & for $(\$ i=0 ; \$ i<\operatorname{count}(\$ c h r o$ & some); $\$ i+$ \\
\hline 7 & $+)\{$ & \\
\hline 8 & $=$ & \\
\hline 9 & for $(\$ j=0 ; \$ j<$ count $(\$ c h r o$ & some $[\$ i])$ \\
\hline 10 & $; \$ j++)\{$ & \\
\hline 11 & & $\$ a[\$ j]=$ \\
\hline 12 & \$chromosome $[\$ i][\$ j][$ 'energi']; & \\
\hline 13 & & $\$ \mathrm{~b}[\$ \mathrm{j}]=$ \\
\hline 14 & \$chromosome $[\$ i][\$ j][$ 'protein']; & \\
\hline 15 & (n) & $\$ c[\$ j]=$ \\
\hline 16 & \$chromosome $[\$ i][\$ j][$ 'lemak']; & \\
\hline 17 & \} & \\
\hline 18 & \$fitne & {$[\$ i]=$} \\
\hline 19 & $1 /($ abs (\$energy-array_sum $(\$ a))+a b$ & \$protein- \\
\hline 20 & array_sum $(\$ b))+a b s(\$ \bar{f} a t-$ & \\
\hline 21 & array_sum(\$c))+\$bilkecil); & \\
\hline 22 & \} & \\
\hline 23 & return $\$$ fitnes & \\
\hline 24 & 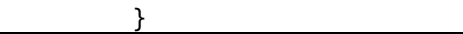 & \\
\hline
\end{tabular}


Penjelasan dari Tabel 7 Kode Program Sistem adalah sebagai berikut:

1. Baris 4 adalah inisialisasi bilangan kecil antara 1-5.

2. Baris 6-22 merupakan perhitungan total energi, total protein dan total lemak dari bahan makanan.

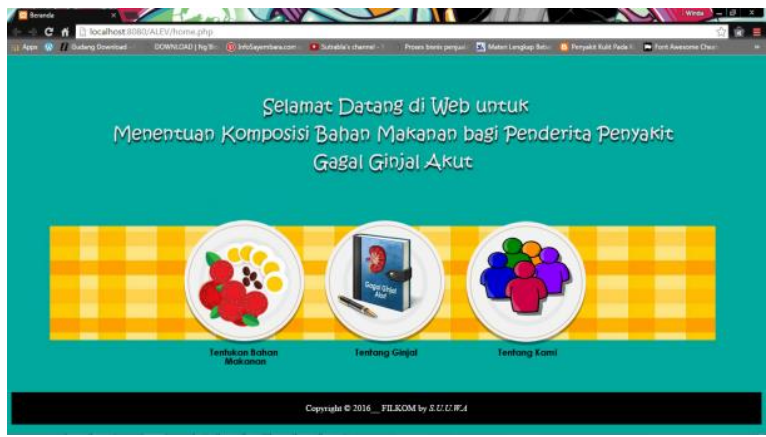

Gambar 3. Antarnuka Halaman Beranda

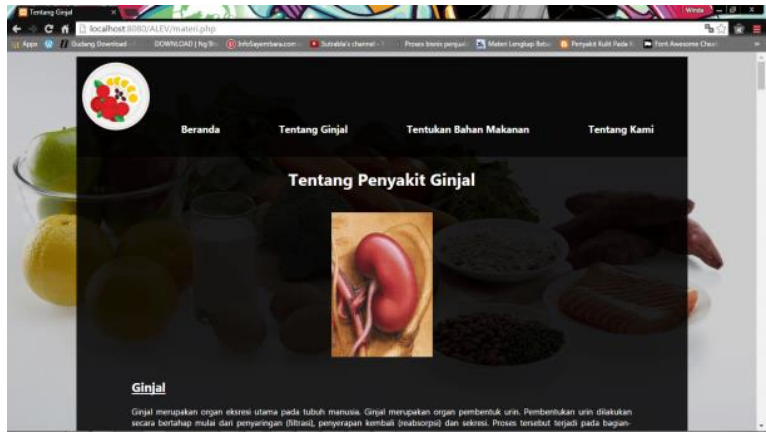

Gambar 4. Antarmuka Halaman Tentang Ginjal

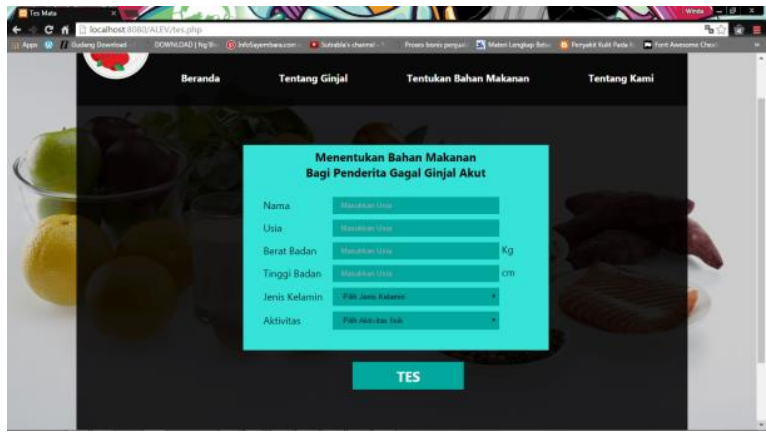

Gambar 5. Antarmuka Halaman Tentukan Bahan Makanan

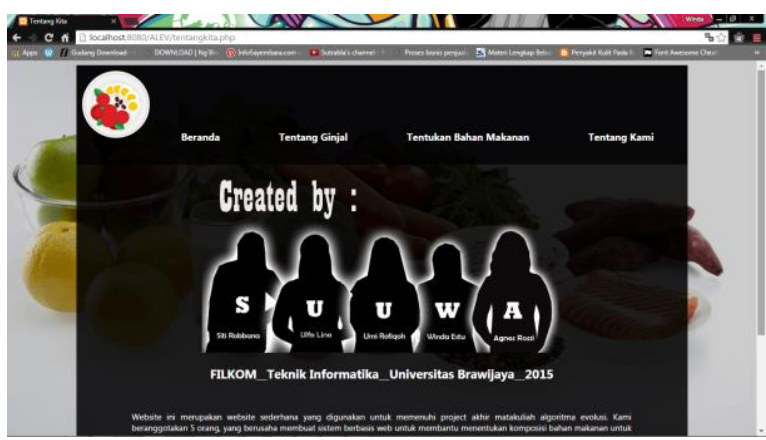

Gambar 6. Antarnuka Halaman tentang Develop
Gambar di atas yaitu Gambar 3, 4, 5 dan 6 merupakan hasil sistem penentuan komposisi bahan makanan bagi penderita gagal ginjal akut dengan algoritma genetika yang telah berhasil diimplementasikan dengan pemrograman php yang masih dijalankan pada localhost developer sistem.

\section{PENGUJIAN DAN ANALISIS}

\subsection{Pengujian Ukuran Populasi}

Pengujian ukuran populasi digunakan untuk mengetahui ukuran populasi terbaik untuk menghasilkan solusi terbaik. Ukuran populasi tersebut akan mempengaruhi besarnya nilai fitness. Ukuran populasi yang diuji coba adalah ukuran yang bervariasi. Pengujian ukuran populasi ini dilakukan sebanyak 6 kali. Hasil pengujian dapat dilihat pada Gambar 7.

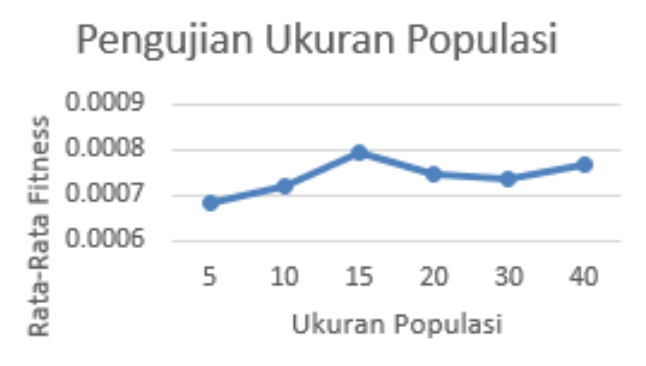

Gambar 7. Hasil Pengujian ukuran populasi

Berdasarkan grafik hasil pengujian pada Gambar 7, rata-rata nilai fitness terbesar didapatkan dari ukuran populasi ke-15 dimana nilai rata-rata fitness-nya telah diketahui sebesar 0.0008. Dari keseluruhan hasil nilai rata-rata yang didapatkan, nilai tersebut mengalami tingkat konvergensi yang kecil. Konvergensi tersebut terjadi karena adanya karena adanya random terhadap tiap inisialisasi chromosome. Sehingga hasil analisis dari grafik di atas menunjukkan bahwa semakin besar populasi maka nilai rata-rata fitness yang didapatkan cenderung semakin besar.

\subsection{Pengujian Banyaknya Generasi}

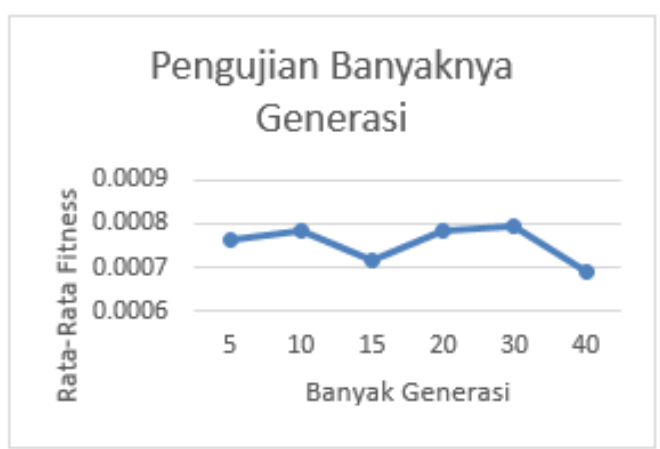

Gambar 8. Pengujian Banyaknya Generasi 
Pengujian banyaknya generasi digunakan untuk mengetahui banyaknya generasi terbaik untuk menghasilkan solusi terbaik. Banyaknya generasi yang diuji adalah $5,10,15,20,30,40$. Pengujian banyaknya generasi ini dilakukan sebanyak 6 kali.

Berdasarkan grafik hasil pengujian pada Gambar 8, rata-rata nilai fitness terbesar didapatkan dari ukuran generasi ke-30 dimana nilai rata-rata fitness-nya telah diketahui sebesar 0.0008. Hasil analisis dari grafik diatas menunjukkan bahwa semakin besar generasi maka nilai rata-rata fitness yang didapatkan cenderung semakin besar. Namun nilai rata-rata fitness juga mengalami penurunan yang signifikan, hal ini karena sifat dari algoritma genetika yaitu stokastik. Stokastik disini adalah terkait hasil solusi yang didapatkan setiap kali melakukan percobaan yang baru selalu cenderung mendapatkan solusi yang berbeda. Sehingga bisa jadi solusi yang didapatkan saat ini tidak lebih baik jika dibandingkan dengan solusi yang didapatkan sebelumnya, dan sebaliknya.

\section{KESIMPULAN DAN SARAN}

Dari serangkaian metodologi, sistem penentuan komposisi bahan makanan bagi penderita gagal ginjal akut dengan algoritma genetika telah berhasil diimplementasikan dengan Bahasa pemrograman PHP yang dijalankan pada localhost developer sistem. Diawali dengan inisialisasi kromosom, kemudian menentukan probabilitas crossover dan mutasinya sehingga mampu melakukan proses reproduksi dengan offspring yang sesuai dengan perhitungan antara probabilitas crossover atau mutasinya. Kemudian dilakukan evauasi dengan perhitungan fitness sesuai dengan rumus, yang dilanjutkan dengan seleksi menggunakan elitsm selection.

Dalam penelitian ini masih terdapat banyak keterbatasan, untuk itu diharapkan pembaca mampu menelaah untuk menjadikan penelitian ini lebih baik dari sebelumnya. Dari latar belakang dan pengujian yang telah dilakukan pada sistem penentuan bahan makanan bagi penderita penyakit gagal ginjal akut didapatkan suatu kesimpulan bahwa sistem mampu memecahkan masalah dalam menentukan komposisi bahan makanan bagi penderita penyakit katastropik, yaitu gagal ginjal akut dengan hasil pengujian yang dilakukan pada ukuran populasi dan banyaknya generasi.

Penelitian dan pembuatan sistem ke depan disarankan untuk memvalidasi kandungan nutrisi dari bahan makanan dan kebutuhan nutrisi dari penderita kepada para pakar atau ahli medis (tidak hanya dari PUGS dan ensiklopedi). Penelitian ini dapat dilanjutkan dengan menambah database dari bahan makanan yang mengandung nilai gizi yang sesuai bagi penderita gagal ginjal akut, membangun user interface yang lebih menarik dan user friendly.

\section{DAFTAR PUSTAKA}

ANONIM1. 2016. Badan Pusat Statistik. www.bps.go.id/, diakses pada tanggal 07 November 2016.

ANONIM2. 2013. Kementrian Kesehatan Republik Indonesia. www.depkes.go.id/, diakses pada tanggal 09 November 2016.

ALMATSIER, S. 2003. Prinsip Dasar Ilmu Gizi. Jakarta : Gramedia Pustaka Utama.

ALMATSIER, S. 2008. Penuntun Diet. Jakarta : Gramedia Pustaka Utama.

DIREKTORAT BINA GIZI, KEMENTERIAN KESEHATAN RI. 2014. Pedoman Gizi Seimbang. http://gizi.depkes.go.id/pgs2014-2. Diakases tanggal 10 November 2016.

HARTATI, SRI, 'UYUN, SHOFWATUL, 2011, 'Computation of Diet Composition for Patients Suffering from Kidney and Urinary Tract Diseases with the Fuzzy Genetic System', International Journal of Computer Applications (0975 - 8887), Volume 36No.6, December 2011.

HARRIS, BENEDICT. 1919. A Biometric Study of Human Basal Metabolism, USA : US National Library of Medicine National Institutes of Health.

ISOKAWA, TEIJIRO \& MATSUI, NOBUYUKI, 2015, 'Performances in GA-based Menu Production for Hospital Meals', Evolutionary Computation (CEC), 2015 IEEE Congress on 25-28 May 2015.

KUSHARDIANA, RESTHY. 2013. 'Penentuan Komposisi Menu Makanan Untuk Penderita Diabetes Mellitus Menggunakan Algoritma Genetika'. Program Studi Ilmu Komputer. Jurusan Teknik Informatika. Program Teknologi Informasi Dan Ilmu Komputer. Universitas Brawijaya. Malang.

MAHMUDY, WF. 2014. Algoritma Evolusi. Program Teknologi Informasi dan Ilmu Komputer. Malang : Universitas Brawijaya.

POP, CB, CHIFU, VR, SALOMIE, I, PRIGOANA, C, BOROS, T \& MOLDOVAN, D, 2016, 'Generating Healthy Menus for Older Adults using a Hybrid Honey Bees Mating Optimization Approach', 17th International Symposium on Symbolic and Numeric Algorithms for Scientific Computing.

PRATIWI, MI, MAHMUDY, WF \& DEWI, C, 2014, 'Implementasi algoritma genetika pada optimasi biaya pemenuhan kebutuhan gizi', DORO: Repository Jurnal Mahasiswa PTIIK Universitas Brawijaya, vol. 4, no. 6. 
RAMAYULIS, R. 2016. Diet Untuk Penyakit Komplikasi. Jakarta: Penebar Plus.

RIANAWATI, A \& MAHMUDY, WF, 2015, 'Implementasi algoritma genetika untuk optimasi komposisi makanan bagi penderita diabetes mellitus', DORO: Repository Jurnal Mahasiswa PTIIK Universitas Brawijaya, vol. 5, no. 14.

WILFRED DRUML, MD， 2001, 'Nutritional Management Of Acute Renal Failure', American Journal of Kidney Diseases Volume 37, Issue 1, Supplement 2, January 2001, Pages S89-S94. 